\title{
Development and Validation of Peaceful Behavior Scale
}

\author{
Latipun \& Ari Firmanto \\ University of Muhammadiyah Malang, Indonesia \\ Email: lativ_un1@yahoo.com
}

\begin{abstract}
Individual behavior basically may be assessed from its peaceful side. From this side, individual behavior may be understood from the tendency of peaceful behavior to conflict behavior. Measurement instrument to understand the tendency of such behavior is in a great need. This research was conducted to the development and validation of Peaceful Behavior Scale (PBS). The participants was 369 Senior/Vocational High School Students from three regencies namely Malang, Lombok Timur and Polewali Mandar. The data were analyzed using an analysis factor. The results showed that PBS consisted of 36 items with the internal consistency (Alpha) of 0.98 , and it is formed from three components namely creating peace, conflict resolution, and anti hostility.
\end{abstract}

Keywords: Scale development, peace behavior, aggression, measurement

\section{BACKGROUND}

In interacting with others, an individual has a tendency to show certain behavior and attitude, but the problem is that whether the behavior and attitude cause a sense of pleasure or not to others. The behavior is called peaceful behavior. Peaceful behavior is a construct in psychology, manifested in the way to respond others in making social relationship, or when one faces and experiences a problem (Latipun, 2010; Latipun, Nasir, Zainah, \& Khairudin, 2012).

Peaceful behavior is developed from the concept of peace. The connotation of "peace" has more meanings of a social atmosphere in the society and in the military world. In its development, peace may be adopted in the construct of individual behavior, meaning individual behavior that produces a peace atmosphere either in the relation to personal or inter-individual relations (Rinehart, 1995). Rinehart's view may be used as a reference in contextualizing peaceful behavior and an individual unit, namely either social or psychological violence between an individual to another individual or to a group.

Various studies on peaceful behavior have been made. This peaceful behavior may happen to individuals at all group either the children, adolescents, or adults. The spectrum of peaceful behavior may cover wide behavior such as violence, conflict resolution, ability in social relationship, and the like (Clayton, Ballif-Spanvill, \& Hunsaker, 2001). Nelson $(2012$, 2014) confirms that peacefulness may be included as trait. Contextually, peacefulness may serve as a trait or as a state, depending on where the tendency is permanent or temporal.

Some terms are used with the same meaning of peaceful behavior, such as constructive conflict resolution (Deutsch, 2011; 1994), peaceful conflict resolution (DuRant, Barkin, \& Krowchuk, 2001). There also researches on peaceful behavior but the variables used are those considered to be in line with the measurement of construct of peaceful behavior such aggression (e.g. Bagwell \& Coie, 2004), and conflicthandling strategy (e.g. Callanan, Benzing, \& Perri, 2006).

Peaceful behavior has wide meanings. It is under a spectrum of the various constructs, not only a not quarrel atmosphere and condition but also individual attitude and behavior that reinforce and support a peaceful atmosphere, a constructive problem solving, and also a social harmonious relation.

Studies on peaceful behavior have been developing in this more complicated society. Peace and efforts to improve peace either individually or collectively are not easy to do, and at the same time conflicts either individually or in groups have always been happening to various communities. As a result, any effort to increase peaceful behavior is always being made through various strategies including peace education, workshop and mediation. However, a more objective and specific measurement of peaceful behavior has not been developed yet.

Until recently, many researches on peaceful behavior or concerned behavior have been made. In the measurement, however, the techniques usually used to measure peaceful behavior are those used to measure conflict resolution (e.g. Hammer, 2005; Henning, 2004), or social relation (e.g Bornstein \& Huprich, 2006), aggression (Buss \& Perry, 1992). If it intends to emasure peaceful behavior more comprehensively it is certainly necessary to combine various relevant instruments as conducted by Latipun et tal. (2012). Nelson (2012) said that a specific instrument for measuring peacefulnes has not existed yet. Therefore, developing an instrument to measure peaceful behavior is very important and beneficial for the sake of a wider study. This present research was conducted to develop and validate an instrument of peaceful behavior special for adolescents.

\section{Elements of Peaceful behavior}

According to World Health Organization (WHO), efforts of peace are classified into three categories: peacemaking, peace-building, and peace-seeking. In the concept of interpersonal relationship, peace keeping is an 
attitude of anti-violence and anti hostility, while peace keeping is an attitude of a constructive problem solving, and peace-building is equivalent with creating-peace dealing with efforts to build friendship or creating peace (Clayton et al., 2001; Latipun, 2010).

Anti Violance and Hostility. Anti violance and hostility is peaceful nehavior mareked by a tendency to avoid, prevent and refuse any violences and behavior that is aggressive, disturbing, provocative and hostile to others (Clayton et al., 2001; Nelson \& Christie, 1995). An individual with peaceful behavior tends to be antiviolance and -hositlity to others.

Strategies of Constructive Conflict Resolutions. Strategy of conflict resolution is peaceful behavior manifested in the ways an individual does in resolvng conflicts and problems with others. The way to solve a problem constructively is made in a peaceful way and the solution is satisfactory for those in conflict. Meanwhile a destructive problem solving is the solution which is not peaceful and is merely for one's satisfaction without taking into account another party's comfort and satisfaction (Clayton et al., 2001; Deutsch, 2001; Nelson \& Christie, 1995). An individual with peaceful behavior has a more tendency to use a constructive conflict resolution than the one with no peaceful behavior

Creating peace. Fostering a good relationship is peaceful behavior marked by one's tendency to build a good relationship with others as the togetherness among them in either conflict or cooperative situations. It is manisfested in the attitude of tolerance, and respect one another about difference, open to others, and the attitude of willingness to help and build a good friendship with others. (Clayton et al., 2001; Nelson \& Christie, 1995). Clayton calls this term creating peace. An individual with peaceful behavior shows his higher ability in making a good friendship with others and may foster and keep a long relationship with others.

\section{RESEARCH METHOD}

\section{Design}

It is a developmental research, namely developing a measurement scale of peaceful behavior for adolescents. Based on various literatures (Hinkin, Tracey, and Enz, 1997; Calton \& Covert, 2007; Osterlind, 1998; Spector, 1992 ) in this present research four stages were made namely: item generation, content adequacy assessment, questionnaire administration, and analysis.

\section{Procedure}

The development of the scale was made by studying literatures on the spectrum of peaceful behavior. From the result of the literature study, an operational term was formulized. An operational definition is derived from three aspects namely anti violence and hostility, constructive problem solving and good social relation. Discussions and evaluations from some parties about the term peaceful behavior are considered in its operation.

Then items dealing with elements on the basis of literature reviews as the indicators of peaceful behavior were formulized. In accordance with the intention of making this instrument to measure peaceful behavior among adolescents, the items were formulized by considering a general pattern existing among adolescents.

Content adequacy assessment. At this stage, experts' judgment was made to evaluate whether the items are adequate or not to measure the chosen variables or constructs. The items that did not fulfill the requirements were eliminated and were not included in the study. Those that are constructively valid were tested to the target subject, namely adolescents to obtain data and they were analyzed in terms of internal consistency, reliability and forming factors of Peaceful Behavior Scale (PBS)

\section{RESEARCH RESULTS}

\section{Study 1}

Overview

The first study was aimed at formulating items of Peaceful Behavior Scale (PBS) on the basis of literature studies of various studies made by experts and researchers in the field of peaceful behavior.

\section{Item Generation}

In line with the literature study, items were organized by taking into account adolescents' attitude, especially those in Indonesian people, and three aspects of peaceful behavior as shown by previous studies. In the initial formulation, 4 items were generated.

\section{Content Validity}

To produce items with content validity, expert's judgment was conducted. In this case, five experts in in psychometrics, psychology and school counseling were asked to validate the instrument. From 45 items formulated on the basis of the experts' judgment, 43 items considered to fulfill the requirements were further tested.

\section{Study 2}

Overview

Study 2 was made to make tests of internal consistency, reliability and factor analysis.

\section{Research Subject}

To analyze the construct validity, reliability, and the forming factor of PBS, a test was administrated to the adolescents in line with their characteristics measured with the instrument. The scale was administrated to 268 students of Senior and Vocational High Schools in Indonesia participating in this testing namely those in Malang (East Java province), Polewali Mandar (West Sulewesi) and Mataram (West Nusa Tenggara). They 
were willing to participate as respondents. Their ages were from 15-17 years $(M=16.3 ; S D=2.64)$. Most subjects were male $(69 \%)$. The subjects in the ages were chosen because from previous researches, they were mostly involved in conflicts (Latipun, 2010). The data were collected by some persons with the tasks to help the researchers after they had got a brief training on data collection.

\section{Data Analysis}

In this research, three categories of validity tests were employed. The first is to use the content validity, namely, making and arranging items which were then continued into internal consistency. The second is to use the construct validity using a factor analysis technique namely Exploratory Factor Analysis (EFA) test.

\section{Internal Consistency}

The PBS Items were stated to be valid from its content. Then a five-Item Likert Scale model from 1 (very inappropriate) to 5 (very appropriate) was made. The test was administrated to the subjects and its internal consistency was analyzed. From the result of the analysis of the item-total correlation corrected (IT), 36 out of 43 items were decided to be valid since they had IT $₫$ higher than 0.30 . The results of the PBS items are presented in Table 1.

Table 1. Analysis of Valid Items of the Peaceful Behavior Scale

\begin{tabular}{|c|c|c|c|}
\hline Statement & Mean & SD & $\mathrm{I}-\mathrm{T}$ \\
\hline It is common if I make others irritated * & 2.39 & 0.95 & 0.40 \\
\hline It is better to lose than to fight with others & 3.07 & 0.95 & 0.40 \\
\hline I remain patient to others who are hostile to me & 2.67 & 0.96 & 0.45 \\
\hline $\begin{array}{l}\text { 4. I can act hard to anyone who bothers my rights } \\
*\end{array}$ & 2.71 & 0.97 & 0.42 \\
\hline $\begin{array}{l}\text { 5. I am not willing to lose to others so that I will } \\
\text { not be looked down } *\end{array}$ & 2.64 & 0.96 & 0.42 \\
\hline 6. I try to forebear when I deal with others & 2.31 & 0.94 & 0.48 \\
\hline I can forgive anyone who are hostile to me & 2.35 & 0.95 & 0.42 \\
\hline $\begin{array}{l}\text { 8. I try to be kind to anyone who shows less } \\
\text { respects to me }\end{array}$ & 2.70 & 0.96 & 0.49 \\
\hline $\begin{array}{l}\text { 9. Almost every day there are someone who } \\
\text { make me angry. }\end{array}$ & 2.75 & 0.96 & 0.35 \\
\hline $\begin{array}{l}\text { 10. I easily eliminate my annoyance when I am } \\
\text { angry with someone }\end{array}$ & 2.61 & 0.96 & 0.37 \\
\hline $\begin{array}{l}\text { 11. When I am insulted, I will avenge the insult to } \\
\text { him/her * }\end{array}$ & 2.34 & 0.96 & 0.41 \\
\hline $\begin{array}{l}\text { 12. When I am irritated, I show my irritation to } \\
\text { others * }\end{array}$ & 2.28 & 0.94 & 0.38 \\
\hline $\begin{array}{l}\text { 13. I don't want to be involved in any quarrels or } \\
\text { fights with others }\end{array}$ & 1.85 & 0.91 & 0.40 \\
\hline 14. I am friendly with many people around me & 1.76 & 0.88 & 0.37 \\
\hline 15. I am not used to bothering others & 2.13 & 0.94 & 0.34 \\
\hline 16. I easily get angry so that I am out of control $*$ & 1.86 & 0.90 & 0.54 \\
\hline 17. I never threaten others & 1.86 & 0.89 & 0.46 \\
\hline $\begin{array}{l}\text { 18. I have a group to prevent any disturbance from } \\
\text { other groups } *\end{array}$ & 2.38 & 0.95 & 0.46 \\
\hline $\begin{array}{l}\text { 19. When I have a problem with others, I ask them } \\
\text { to solve it }\end{array}$ & 2.61 & 0.95 & 0.36 \\
\hline
\end{tabular}


the factor analysis, Initial Eigenvalues above $1(\geq 1)$ namely 12 factors was obtained where it is higher than what is estimated namely 1 factor. Then the screen plot display is the explanation of the table of the total variance explained. Picture 1 is the screen plot showing the formed the loading factor, so that it can be concluded that the instrument of peaceful behavior forms 3 components, as shown in Picture 1.

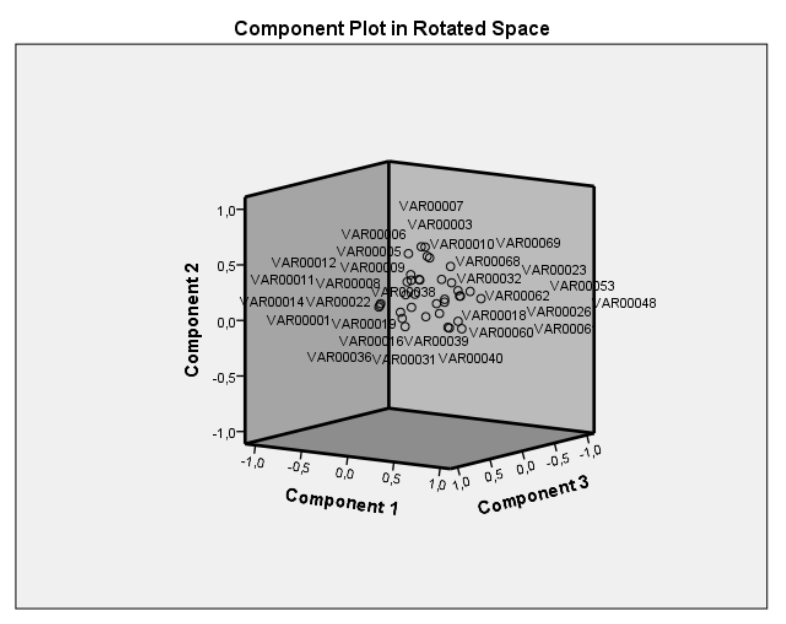

To obtain a good factor, Rotated Component Matrix was made. The result of the analysis showed that all PBS items is above the cut of point of 0.30 , where the loading factor obtained is from 0.80 t o 0.91 . Based on the score, it can be concluded all statement items grouped in the three factors are valid as presented in Table 2 .

\begin{tabular}{|c|c|c|c|c|}
\hline 32 & $\begin{array}{l}\text { I feel that there are many people who } \\
\text { take advantage of me by making use of } \\
\text { my weaknesses }\end{array}$ & 0.80 & 0.51 & \\
\hline 33 & $\begin{array}{l}\text { I can make friends with anyone who was } \\
\text { once hostile to me }\end{array}$ & 0.91 & 0.42 & \\
\hline 34 & $\begin{array}{l}\text { Those out of my group tend to behave } \\
\text { negatively }\end{array}$ & 0.89 & 0.38 & \\
\hline 35 & It is natural if others do good to me & 0.87 & 0.41 & \multirow{12}{*}{$\begin{array}{l}\text { Factor } \\
2: \\
\text { Confli } \\
\text { ct } \\
\text { resolu } \\
\text { tion }\end{array}$} \\
\hline 2 & $\begin{array}{l}\text { It is better to lose than to fight with } \\
\text { others }\end{array}$ & 0.87 & 0.63 & \\
\hline 3 & $\begin{array}{l}\text { I remain patient to others who are hostile } \\
\text { to me }\end{array}$ & 0.89 & 0.59 & \\
\hline 4 & $\begin{array}{l}\text { I can act hard to anyone who bothers my } \\
\text { rights }\end{array}$ & 0.87 & 0.64 & \\
\hline 5 & $\begin{array}{l}\text { I am not willing to lose to others so that } \\
\text { I will not be looked down }\end{array}$ & 0.84 & 0.55 & \\
\hline 7 & $\begin{array}{l}\text { I can forgive anyone who are hostile to } \\
\text { me }\end{array}$ & 0.86 & 0.38 & \\
\hline 8 & $\begin{array}{l}\text { I try to be kind to anyone who shows less } \\
\text { respects to me }\end{array}$ & 0.89 & 0.57 & \\
\hline 9 & $\begin{array}{l}\text { Almost every day there are someone } \\
\text { who make me angry }\end{array}$ & 0.84 & 0.36 & \\
\hline 10 & $\begin{array}{l}\text { I easily eliminate my annoyance when I } \\
\text { am angry with someone }\end{array}$ & 0.81 & 0.41 & \\
\hline 18 & $\begin{array}{l}\text { I have a group to prevent any } \\
\text { disturbance from other groups }\end{array}$ & 0.85 & 0.38 & \\
\hline 22 & $\begin{array}{l}\text { When I am sure that my opinion is right, } \\
\text { I try to convey my argument well }\end{array}$ & 0.82 & 0.35 & \\
\hline 23 & $\begin{array}{l}\text { I try to listen to one's opinion which is } \\
\text { different from mine }\end{array}$ & 0.80 & 0.47 & \\
\hline 1 & It is common if I make others irritated & 0.85 & 0.62 & \multirow{11}{*}{$\begin{array}{l}\text { Factor } \\
3 \text { : } \\
\text { Anti } \\
\text { hostili } \\
\text { ty }\end{array}$} \\
\hline 6 & I try to forebear when I deal with others & 0.91 & 0.41 & \\
\hline 11 & $\begin{array}{l}\text { When I am insulted, I will avenge the } \\
\text { insult to } \mathrm{him} / \mathrm{her}\end{array}$ & 0.85 & 0.41 & \\
\hline 12 & $\begin{array}{l}\text { When I am irritated, I show my irritation } \\
\text { to others }\end{array}$ & 0.83 & 0.62 & \\
\hline 13 & $\begin{array}{l}\text { I don't want to be involved in any } \\
\text { quarrels or fights with others }\end{array}$ & 0.83 & 0.54 & \\
\hline 14 & $\begin{array}{l}\text { I am friendly with many people around } \\
\text { me }\end{array}$ & 0.81 & 0.36 & \\
\hline 15 & I am not used to bothering others & 0.79 & 0.47 & \\
\hline 16 & $\begin{array}{l}\text { I easily get angry so that I am out of } \\
\text { control }\end{array}$ & 0.91 & 0.48 & \\
\hline 17 & I never threaten others & 0.87 & 0.48 & \\
\hline 20 & $\begin{array}{l}\text { When someone has an opposite opinion } \\
\text { with mine, I insinuate him/her so that } \\
\text { s/he is embarrassed }\end{array}$ & 0.87 & 0.54 & \\
\hline 36 & $\begin{array}{l}\text { I am difficult to accept anyone who likes } \\
\text { to criticize me }\end{array}$ & 0.82 & 0.53 & \\
\hline
\end{tabular}

Therefore in brief it can be stated that the PBS items consist of three factors namely creating peace (14 items), problem solving (12 items), and anti hostility (11 items). On the basis of the Principal Component Analysis, it is known that the contribution of each factor to the instrument as a whole is $0.60,0.68$ and 0.43 , respectively.

\section{DISCUSSION}

The PBS instrument tested in this study has produced a conclusion that the PBS established has fulfilled validity and reliability. This study has given an answer to the weakness of this instrument to measure peaceful behavior special for adolescents. In this present research, the PBS consists of three factors namely creating peace, conflict resolution, and anti hostility. 
The three factors formed are in line with previous studies emphasizing that the peace includes three aspects namely peacemaking, peace keeping and peace building. The three types of peace handling models in the society may also be applied for peace behavior at the individual level.

Reinforcement of this research results shows that behavior among adolescents also include these three factors, although peace behavior is more dominant in the two main aspects namely creating peace and anti hostility, while the constructive resolution aspect has not emerge, but it is still potential in nature.

Viewed from the side of the reliability score, this instrument obtained Alpha of 0.89 , where it is a very good value. It means that it has a very good internal consistency and reliability. Therefore, this instrument principally may be used to measure peaceful behavior, but it is necessary to make further analyses to produce a good instrument by comparing it with other similar instruments to know whether this PBS instrument has a good correlation or not. Then, it is also necessary to study this instrument in terms of its reliability for wider subjects.

\section{CONCLUSION}

This present research has produced a decision that the PBS established consists of 36 items containing three factors namely creating peace, conflict resolution, and anti hostility. The BPS items have a good reliability with the results of the internal consistency (alpha) of 0.89 . Among the three factors forming the PBS, the one with the most contribution is creating peace aspect, followed by conflict resolution and then anti hostility. This instrument should be further testet by comparing it with similar instruments to reinforce its validity and reliability

\section{BIBLIOGRAPHY}

Bagwell, C. L., \& Coie, J. D. (2004). The best friendships of aggressive boys: Relationship quality, conflict management, and rule-breaking behavior. Journal of Experimental Child Psychology, 88(1), 5-24. https://doi.org/10.1016/j.jecp.2003.11.004

Bornstein, R. F., \& Huprich, S. K. (2006). Construct validity of the relationship profile test: three-year retest reliability and links with core personality traits, object relations, and interpersonal problems. Journal of Personality Assessment, $\quad 86(2), \quad 162-171$. https://doi.org/10.1207/s15327752jpa8602_05

Buss, A. H., \& Perry, M. (1992). The aggression questionnaire. Journal of Personality and Social Psychology, 63, 452459.

Callanan, G. a, Benzing, C. D., \& Perri, D. F. (2006). Choice of conflict-handling strategy: A matter of context. The Journal of Psychology, 140(3), 269-288. https://doi.org/10.3200/JRLP.140.3.269-288

Clayton, C. J., Ballif-Spanvill, B., \& Hunsaker, M. D. (2001). Preventing violence and teaching peace: A review of promising and effective antiviolence, conflict-resolution, and peace programs for elementary school children.
Applied \& Preventive Psychology, 10. 1-35. https://doi.org/10.1016/S0962-1849(05)80030-7

Deutsch, M. (1994). Constructive Conflict Resolution: Principles , Training, and Research. Journal of Social Issues, 50(1), 13-32.

Deutsch, M. (2001). Cooperation and conflict resolution: Implications for consulting psychology. Consulting Psychology Journal: Practice and Research, 53(2), 7681. https://doi.org/10.1037//1061-4087.53.2.76

Deutsch, M. (2011). Conflict, Interdependence, and Justice. In P. . Deutsch, M. \& Coleman (Ed.), The handbook of conflict resolution: theory and practice (pp. 23-41). San Francisco: Jossey-Bass Publisher. https://doi.org/10.1007/978-1-4419-9994-8

DuRant, R. H., Barkin, S., \& Krowchuk, D. P. (2001). Evaluation of a peaceful conflict resolution and violence prevention curriculum for sixth-grade students. Journal of Adolescent Health, 28(5), 386-393. https://doi.org/10.1016/S1054-139X(00)00194-4

Hammer, M. R. (2005). The Intercultural Conflict Style Inventory: A conceptual framework and measure of intercultural conflict resolution approaches. International Journal of Intercultural Relations, $29(6$ SPEC. ISS.), 675-695. https://doi.org/10.1016/j.ijintrel.2005.08.010

Henning, M. (2004). Reliability of the conflict resolution questionnaire: Considerations for using and developing internet-based questionnaires. Internet and Higher Education, 7(3), 247-258. https://doi.org/10.1016/j.iheduc.2004.06.005

Latipun, L. (2010). Kaunseling dan perdamaian: keberkesanan kaunseling berfokus resolusi konflik antara rakan sebaya bagi peningkatan tingkah laku aman dalam kalangan remaja. Malang: Psycology Forum.

Latipun, S., Nasir, R., Zainah, A. Z., \& Khairudin, R. (2012). Effectiveness of peer conflict resolution focused counseling in promoting peaceful behavior among Adolescents. Asian Social Science, 8(9), 8-16. https://doi.org/10.5539/ass.v8n9p8

Nelson, L. L. (2012). Peaceful Personality. In The Encyclopedia of Peace Psychology (First Edit, pp. 1-5). Blackwell Publishing Ltd.

Nelson, L. L. (2014). Peacefulness as a personality trait. In G. K. Sims et al. (eds.) (Ed.), Peace Psychology (Vol. 20. pp. 7-18). New York: Springer Science. https://doi.org/10.1007/978-1-4614-9366-2

Nelson, L. L., \& Christie, D. J. (1995). Peace in the psychology curriculum: moving from assimilation to accommodation. Peace and Conflict: Journal of Peace Psychology, 1(2), 1661-178.

Rinehart, M. (1995). Understanding the concept "peace": A Search for common ground. Peace \& Change, 20(3), 375-396. 